\title{
Low-Carbon Design Path of Building Integrated Photovoltaics: A Comparative Study Based on Green Building Rating Systems
}

\author{
Ke Liu ${ }^{1,2}$, Beili Zhu ${ }^{1,2}$ and Jianping Chen ${ }^{1,2,3, *}$ \\ 1 School of Architecture and Urban Planning, Suzhou University of Science and Technology, \\ Suzhou 215009, China; 1k@mail.usts.edu.cn (K.L.); 1911011016@post.usts.edu.cn (B.Z.) \\ 2 Jiangsu Province Key Laboratory of Intelligent Building Energy Efficiency, \\ Suzhou University of Science and Technology, Suzhou 215009, China \\ 3 Department of Scientific Research, Chongqing Innovation Center for Industrial Big Data, \\ Chongqing 400700, China \\ * Correspondence: alan@mail.usts.edu.cn
}

Citation: Liu, K.; Zhu, B.; Chen, J. Low-Carbon Design Path of Building Integrated Photovoltaics: A Comparative Study Based on Green Building Rating Systems. Buildings 2021, 11, 469. https://doi.org/ 10.3390 /buildings11100469

Academic Editors: Ayyoob Sharifi, Baojie He, Chi Feng and Jun Yang

Received: 11 September 2021

Accepted: 8 October 2021

Published: 13 October 2021

Publisher's Note: MDPI stays neutral with regard to jurisdictional claims in published maps and institutional affiliations.

Copyright: (C) 2021 by the authors Licensee MDPI, Basel, Switzerland. This article is an open access article distributed under the terms and conditions of the Creative Commons Attribution (CC BY) license (https:// creativecommons.org/licenses/by/ $4.0 /)$

\begin{abstract}
CO}_{2}$ emissions of buildings have a critical impact on the global climate change, and various green building rating systems (GBRS) have suggested low-carbon requirements to regulate building emissions. Building-integrated photovoltaics (BIPV), as an integrated technology of photovoltaics and buildings, is an important way to reduce building $\mathrm{CO}_{2}$ emissions. At present, the low-carbon design path of BIPV from architecture is still not unified and clear, and there is a lack of BIPV research regarding GBRS or from the perspective of architectural design in China. The objective of this study is to propose a framework of indicators related to carbon emission control in BIPV, guiding the path of BIPV low-carbon design. This study makes comparisons among the Leadership in Energy and Environmental Design (LEED), Building Research Establishment Environmental Assessment Method (BREEAM), and Assessment Standard for Green Buildings (ASGB), mainly in terms of the scope weight, induction, and measure features. The BIPV low-carbon design involves energy, materials, environmental adaptability, management, and innovation, in which energy and materials are the main scopes with weights of $10.98 \%$ and $7.46 \%$, respectively. The five scopes included 17 measures. Following the measures, the path of the BIPV low-carbon design was defined with six aspects.
\end{abstract}

Keywords: building-integrated photovoltaics (BIPV); low-carbon design; green building rating systems (GBRS); $\mathrm{CO}_{2}$ emissions; comparative study

\section{Introduction}

Global greenhouse gas (GHG) emissions have caused several problems, including social problems, global warming, and energy supply shortage [1]. Countries and districts have proposed carbon-neutral goals and related policies. China faces a serious carbon emission problem, accounting for $27.9 \%$ of the world's total emissions [2]. China has announced its ambitious goal to peak carbon dioxide emissions by 2030 and achieves carbon neutrality before 2060 in the upgraded Nationally Determined Contributions [3] to respond to climate change positively. To achieve these goals, decarbonization of the building industry is important. Buildings account for $36 \%$ of the global final energy consumption and almost $40 \%$ of the total direct and indirect $\mathrm{CO}_{2}$ emissions [4]. Building energy consumption accounted for $46.5 \%$ of the total energy consumption in China in 2018, resulting in carbon emissions accounting for approximately $51.3 \%$ of the total [5]. Low-carbonization of the building industry is essential to determine whether China can meet its international targets. Optimisation of building energy consumption structure is an important means of reducing building carbon emissions, and the deployment of renewable energy sources in the built environment is a key step towards the reduction of fossil fuel consumption in the building sector [6]. Renewable energy sources can occupy a growing share of the total energy consumption of the building. [7] Among these, building-integrated photovoltaics (BIPV), 
as a cutting-edge technology that combines photovoltaics with buildings, is generally considered to be the mainstream direction for sustainable building development [8]. In terms of BIPV, photovoltaic (PV) technology is particularly suitable as a renewable energy source owing to its stable market increase and price reduction [9]; in addition to generating electricity, BIPV modules perform at least one additional function, such as insulation, weather barrier, or sun shading [8].

At present, there is no unified concept for the BIPV. The International Standard Organization (ISO) shows that BIPV is a photovoltaic material that is used to replace conventional building materials in parts of the building envelope [10], and the International Electrotechnical Commission (IEC) shows that BIPV is a PV module that is considered to be building-integrated if the PV modules form a building component providing additional functions [11]. In Korea, building-integrated photovoltaic modules are considered to be building components installed as parts of the building envelope, such as glazing, curtain walls, and roofs, which are simultaneously photovoltaic electricity generators [12]. The Spanish Technical Building Code mentioned architectural integration of photovoltaic modules in which solar installations should be aligned with the main axes of the building [13]. There are various topics in BIPV research, such as aesthetics [14], adaptation [15], ecology [16], enhancement of materials [17,18], glare assessment [19] and energy savings [20,21]. Kapsis and Athenitis focused on the optical performance of BIPV [22], and Skandalos and Karamanis investigated the thermal performance of semi-transparent PV technologies. Although there are a number of examples of BIPV, the concept of integration into the building and its design process have not yet been clearly defined [23]. As BIPV has a broad market prospect and many manufacturers are involved in the production of BIPV products, a considerable part of the products is manufactured by simple modifications of ordinary photovoltaic modules, and such products are unable to meet the requirements of the building ontology [24].

Though dye-sensitized solar cells have been integrated into glass devices as a transparent building component, the related studies paid more attention to the improvement of material properties from the perspective of physics and chemistry, and rarely mentioned reasonable use $[25,26]$. It is obvious that the current BIPV-related standards are mostly from the perspective of photovoltaic technology and electrical or product quality standards and lack design guidance from an architectural perspective. The studies related to BIPV paid more attention to the building physical environment and attributes of equipment efficiency and little on the architectural design. Lack of interest is correlated to various bottlenecks, and one of them is a lack of knowledge among architects on the possibilities and approaches to adopt architectural photovoltaic applications (APA) [27]. Although issues concerning BIPV in architectural design are discussed in China [28], the low-carbon design of BIPV is seldom mentioned. BIPV is not only a photovoltaic power technology, but also a concrete measure of green building design [29]. Facing the urgent requirement of building carbon neutrality, it is necessary to define a low-carbon design path framework from an architectural perspective.

There is an increasing number of studies on $\mathrm{CO}_{2}$ emissions from buildings because aggravated climate changes have placed $\mathrm{CO}_{2}$ emissions at the centre of green building rating system (GBRS) evaluations of building sustainability [30]. The promotion of green building concepts is essential for all countries, especially in developing countries, green buildings are developed through the use of GBRS [31]. As one of the most effective solutions for creating green buildings, the indicators of the low-carbon design of BIPV can be summarised based on the studies on GBRS. Here, we comparatively studied $\mathrm{CO}_{2}-$ related indicators of BIPV in three GBRS-Leadership in Energy and Environmental Design (LEED), Building Research Establishment Environmental Assessment Method (BREEAM) and Assessment Standard for Green Buildings (ASGB), and a framework of indicators related to carbon emission control in BIPVs was developed based on ASGB-2019. The study provides suggested scopes, order of importance, related measures, and the path of BIPV 
low-carbon design, which is the first such attempt from the architectural perspective in this field.

\section{Methodology}

The primary objective of this paper is to study the related indicators of $\mathrm{CO}_{2}$ emission control in BIPV from different GBRS. First, the characteristics of each GBRS were clarified through a literature survey. To make the comparison referential, the latest versions of the GBRS were used in this study: LEEDv4.1, BREEAM INC 2016, and ASGB-2019. The following comparative analysis of the related indicators in the GBRS included four factors: scope of coverage, evaluation content, weight, and contribution rate. Based on the comparison, the similarities and differences of indicators among the different GBRS were discussed, a framework of $\mathrm{BIPV} \mathrm{CO}_{2}$ emissions control measures was introduced, and the normal form of the BIPV low-carbon design path was proposed. The study schema is shown in Figure 1.

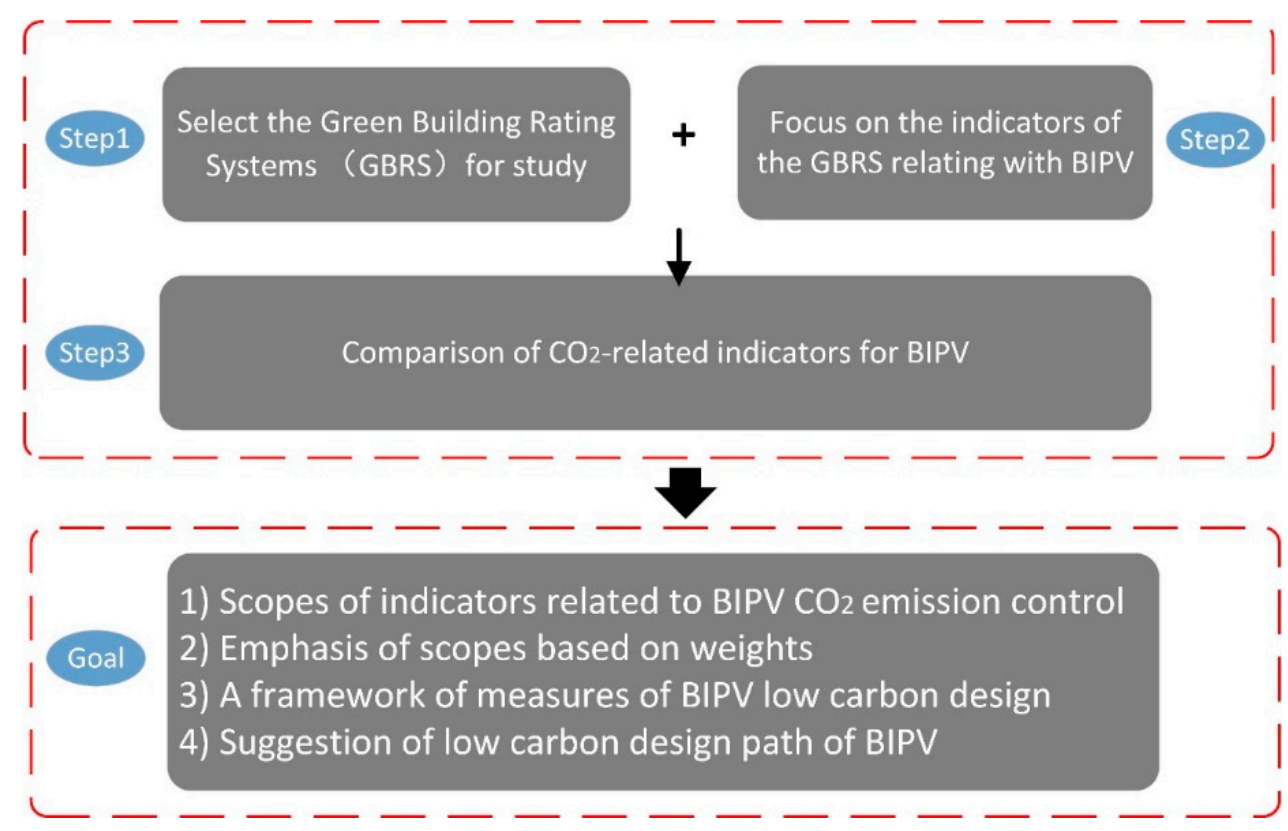

Figure 1. The study schema.

\subsection{Definition of BIPV from the Perspective of Architectural Design}

Most definitions of BIPV are from the perspective of electrical specialty, components, and materials, while consideration of architectural design is rare. The problem of BIPV product design exposes the lack of integration between photovoltaic (PV) and building industries, and the low participation of architects, which hinders the promotion and development of BIPV. Many building practitioners admit that there is a gap in the knowledge of the potential and supporting technologies of BIPV [32]. It is difficult to integrate PV technology into building projects [33]. PV technology used in buildings has proven to be an effective technological approach to reduce the carbon emissions of building operations. Integration of PV technology and other renewable energy technologies has an important role in providing a long-term energy supply with little emissions [34]. Moreover, there is a growing consensus that BIPV systems will be the backbone of the zero-energy building (ZEB) European target by 2020 [35]. Studies have confirmed that the electricity provided by BIPV can reduce a considerable amount of $\mathrm{CO}_{2}$ per year [36]. BIPV systems could be used in different contexts and building types [37]. However, if the low-carbon design of the BIPV cannot be realised, the contribution of BIPV to carbon emission reduction will be significantly reduced. This study defines BIPV from the perspective of the architectural design of a green building that integrates the design of a photovoltaic system with building 
elements, ensuring that the use of photovoltaic systems will not affect the functionality, safety, and artistry of the building.

\subsection{Literature Surveys of Selected Assessment Systems}

The selection of GBRS is based on its development relationships, worldwide recognition, and the global building market. BREEAM, as the world's first green building assessment standard, has a moderate structure and hierarchy and a proper number of standard items, making sure the standard is operable and scientific. LEED was developed on the basis of BREEAM, and it is one of the most widely used and influential green building identification certification systems, which has become a reference model for various countries. The primary references in the initial revision of the ASGB were LEED and BREEAM. ASGB is the foundation of the environmental rating systems in China which has the largest construction market in the world [38]. We selected the latest versions of each GBRS, which are BREEAM INC 2016, LEEDv4.1 BD + C, and ASGB-2019.

\subsubsection{BREEAM International New Construction 2016 (BREEAM INC 2016)}

The BREEAM International New Construction 2016 scheme can be used to assess the environmental life-cycle impacts of new buildings at the design and construction stages [39]. It includes 10 criteria: Management, Health and Well-being, Energy, Transport, Water, Materials, Waste, Land Use and Ecology, Pollution, Innovation (Table 1). The total score should be calculated using Equation (1). Among the criteria, the six aspects related to BIPV $\mathrm{CO}_{2}$ emission control are management, health and well-being, energy, materials, waste, and innovation.

$$
Q_{B R E E A M}=\sum_{i=1}^{10} \frac{W_{i} Q_{B R E E A M}^{i}}{\operatorname{Tot}_{i}}
$$

Here, $Q_{B R E E A M}$ is the total score of the BREEAM indicators; $W_{1}-W_{10}$ are the weights of the ten indicators; $Q_{B R E E A M}^{1}-Q_{B R E E A M}^{10}$ are scoring item scores of the ten indicators; and $\operatorname{Tot}_{1}-\mathrm{Tot}_{10}$ are the total scores of the ten indicators.

Table 1. Criteria of BREEAM INC 2016.

\begin{tabular}{ccc}
\hline Criteria & Score & Weighting \\
\hline Management $^{*}$ & 21 & $11 \%$ \\
Health and Well-being * $^{*}$ & 25 & $10.5 \%$ \\
Energy * $^{*}$ & 34 & $15 \%$ \\
Transport $_{\text {Water }}^{*}$ & 13 & $10 \%$ \\
Materials $^{\text {Waste }}$ & 10 & $7.5 \%$ \\
Land use and ecology & 12 & $14.5 \%$ \\
Pollution & 10 & $9.5 \%$ \\
Total & 10 & $11 \%$ \\
\hline Innovation * & 13 & $11 \%$ \\
\hline
\end{tabular}

${ }^{*}$ Aspects related to $\mathrm{BIPV} \mathrm{CO}_{2}$ emission control.

\subsubsection{LEED Building Design and Construction Version 4.1 (LEEDv4.1 BD + C)}

LEED v4.1 is the next-generation standard for green building design, construction, operation, and performance, and LEED for Building Design and Construction (LEED BD + C) provides a framework for building a holistic green building that has options to fit every project [40]. It includes nine criteria: Integrative Process, Location and Transportation, Sustainable Sites, Water Efficiency, Energy and Atmosphere, Materials and Resources, Indoor Environmental Quality, Innovation, and Regional Priority (Table 2). The total score should be calculated using Equation (2). Among the criteria, the six aspects related to BIPV $\mathrm{CO}_{2}$ emission control are Integrative Process, Sustainable Sites, Energy and Atmosphere, 
Materials and Resources, Indoor Environmental Quality, Innovation. From the very beginning of the LEED system, a common assumption was that it would reduce the energy consumption of buildings and limit GHG emissions [41-43].

$$
Q_{L E E D}=Q_{L E E D}^{1}+Q_{L E E D}^{2}+Q_{L E E D}^{3}+Q_{L E E D}^{4}+Q_{L E E D}^{5}+Q_{L E E D}^{6}+Q_{L E E D}^{7}+Q_{L E E D}^{8}+Q_{L E E D}^{9}
$$

Here, $Q_{L E E D}$ is the total score of LEED indicators and $Q_{L E E D}^{1}-Q_{L E E D}^{9}$ are scores of the nine indicators.

Table 2. Criteria of LEEDv4.1 BD + C.

\begin{tabular}{|c|c|}
\hline Criteria & Score \\
\hline Integrative Process $*\left(Q_{L E E D}^{1}\right)$ & 1 \\
\hline Location and Transportation $\left(Q_{L E E D}^{2}\right)$ & 16 \\
\hline Sustainable Sites $*\left(Q_{I F F D}^{2}\right)$ & 10 \\
\hline Water Efficiency $\left(Q_{L E E D}^{4}\right)$ & 11 \\
\hline Energy and Atmosphere $*\left(Q_{L E E D}^{5}\right)$ & 33 \\
\hline Materials and Resources $*\left(Q_{I F E D}^{6}\right)$ & 13 \\
\hline Indoor Environmental Quality $*\left(Q_{L E E D}^{P}\right)$ & 16 \\
\hline Innovation $*\left(Q_{L E E D}^{8}\right)$ & 6 \\
\hline Regional Priority $\left(Q_{L E E D}^{9}\right)$ & 4 \\
\hline Total $\left(Q_{\text {LEED }}\right)$ & 110 \\
\hline
\end{tabular}

\subsubsection{Assessment Standard for Green Buildings GB/T 50378-2019 (ASGB-2019)}

The latest version of the Assessment Standard for Green Buildings is GB/T 503782019, which is ASGB-2019 [44]. ASGB-2019 includes five required indicators: Safety and Durability, Health and Comfort, Occupant Convenience, Resources Saving, Environment Livability, and one bonus indicator, Promotion and Innovation (Table 3). The total score should be calculated using Equation (3). Among the criteria, the five aspects related to BIPV $\mathrm{CO}_{2}$ emission control are Safety and Durability, Health and Comfort, Occupant Convenience, Resources Saving, and Promotion and Innovation.

$$
Q_{A S G B}=\left(Q_{0}+Q_{1}+Q_{2}+Q_{3}+Q_{4}+Q_{5}+Q_{A}\right) / 10
$$

Here, $Q_{A S G B}$ is the total score of the ASGB indicators; $Q_{0}$ is the required base score, which is 400 when all prerequisite items are met; $Q_{1}-Q_{5}$ are scoring item scores of the five required indicators; $Q_{A}$ is the bonus score of Promotion and Innovation.

Table 3. Criteria of ASGB-2019.

\begin{tabular}{ccc}
\hline Attribute of Items & Criteria & Score \\
\hline Prerequisite items & & 400 \\
\hline & Safety and Durability * & 100 \\
Scoring items & Health and Comfort * & 100 \\
& Occupant Convenience * & 100 \\
& Resources Saving * & 200 \\
Bonus items & Environment Livability & 100 \\
Total & Promotion and Innovation * & 100 \\
\hline
\end{tabular}

* Aspects related to BIPV $\mathrm{CO}_{2}$ emission control.

\subsection{Criteria-Based Tools Comparison}

There are two types of approaches that have been followed for implementing the rating systems: criteria-based tools and life cycle assessment (LCA) [45]. The problem in using the LCA method for buildings stems from the fact that the production process is complicated and the life span of a building is long, where future phases are based 
on assumptions [38]. The criteria-based tool comparison in this paper mainly makes a horizontal comparison of three GBRS, divided into overall comparison and the same aspect of the evaluation in GBRS. Specifically, the comparisons are conducted on the scope of coverage, weight, evaluation content, and measure features.

\subsection{Quantitative Research Method: Weight Calculation (WC)}

In terms of the comparison, we not only clarify every indicator instruction qualitatively but also investigate the $\mathrm{CO}_{2}$ emission control-related indicators of BIPV in the quantitative method, which is called weight calculation (WC).

WC is a quantitative analysis of the weight of indicators related to the BIPV lowcarbon design in every GBRS. The purpose of WC is to measure the proportion of indicator scores related to BIPV low-carbon design in the whole GBRS. Referring to Equation (1), the indicator scores are influenced by the indicators' weights in BREEAM. BREEAM INC 2016 provides a weighting system itself, and the proportion of points related to $\mathrm{BIPV} \mathrm{CO}_{2}$ emission control is calculated using Equation (4).

$$
B_{B R E E A M}^{i}=P_{B R E E A M}^{i} W_{B R E E A M}^{i} / T_{B R E E A M}^{i}
$$

Here, $B_{B R E E A M}^{i}$ is the weight of indicators related to BIPV low-carbon design in category $i$ of BREEAM INC 2016; $P_{B R E E A M}^{i}$ is the maximum score of indicators related to BIPV $\mathrm{CO}_{2}$ emission control of category $i ; T_{B R E E A M}^{i}$ is the total score of criteria in category $i$; and $W_{B R E E A M}^{i}$ is the weight of every criterion.

Neither LEED v4.1 nor ASGB-2019 has a weighting system; thus, the weight is calculated by dividing the item score by the total score of the indicators. The weight of the indicators related to BIPV $\mathrm{CO}_{2}$ emission control was calculated using Equation (5) in LEEDv4.1 BD + C.

$$
B_{L E E D}^{i}=P_{L E E D}^{i} / T_{L E E D}
$$

Here, $B_{L E E D}^{i}$ is the weight of indicators related to the BIPV low-carbon design in category $i$ of LEEDv4.1 BD $+C ; P_{L E E D}^{i}$ is the maximum score of indicators related to BIPV $\mathrm{CO}_{2}$ emission control of category $i$; and $T_{L E E D}$ is the total score of indicators in LEEDv4.1 $\mathrm{BD}+\mathrm{C}$.

The weight of the indicators related to BIPV $\mathrm{CO}_{2}$ emission control was calculated using Equation (6) in ASGB-2019.

$$
B_{A S G B}^{i}=P_{A S G B}^{i} /\left(T_{A S G B}-400\right)
$$

Here, $B_{A S G B}^{i}$ is the weight of indicators related to the BIPV low-carbon design in category $i$ of ASGB-2019; $P_{A S G B}^{i}$ is the maximum score of indicators related to $\mathrm{BIPV} \mathrm{CO}_{2}$ emission control of category $i$; and $T_{A S G B}$ is the total score of indicators without division in ASGB-2019.

\section{Results}

Following the comparative analysis, the BIPV $\mathrm{CO}_{2}$-related indicators in the three GBRS were listed according to the types stated previously, and the comparison was carried out based on the following aspects: scope, weight, induction, and measure features.

\subsection{Analysis of Scopes of Related Indicators}

Based on the study of categories involved in $\mathrm{BIPV} \mathrm{CO}_{2}$ emission control in three GBRS, the scopes of related indicators are summarised. In terms of the indicators related to BIPV $\mathrm{CO}_{2}$ emission control, BREEAM INC 2016 includes six categories: Management (Man), Health and Well-being (Hea), Energy (Ene), Materials (Mat), Waste (Wst), and Innovation (Inn); LEEDv4.1 BD + C includes five categories, which are Integrative Process (IP), Energy and Atmosphere (EA), Materials and Resources (MR), Indoor Environmental Quality (EQ), and Innovation (IN). ASGB-2019 includes five categories, which are Safety and durability (S\&D), Health and comfort (H\&C), Occupant convenient (OC), Resource saving (RS), and 
Promotion and innovation (P\&I). Among them, Ene in BREEAM, EA and 'Evaluation and analysis of energy-related systems' of IP in LEED, and RS in ASGB could be generalised to Energy scope. Mat and Wst in BREEAM, MR in LEED, and S\&D and 'Material Saving and Green Materials' of RS in ASGB could be generalised to material scope. Man in BREEAM, 'Fundamental commissioning and verification' of EA in LEED, and OC in ASGB could be generalised to management scope. The indoor air quality (Hea 02) of Hea in BREEAM, EQ in LEED, and 'Indoor Thermal Environment' of H\&C in the ASGB could be generalised to the environmental adaptability scope. Inn in BREEAM, IN in LEED, and P\&I in ASGB could be generalised to the innovation scope. In summary, the indicators related to BIPV $\mathrm{CO}_{2}$ emission control mainly involve five aspects: energy, materials, management, environmental adaptability, and innovation (Figure 2).

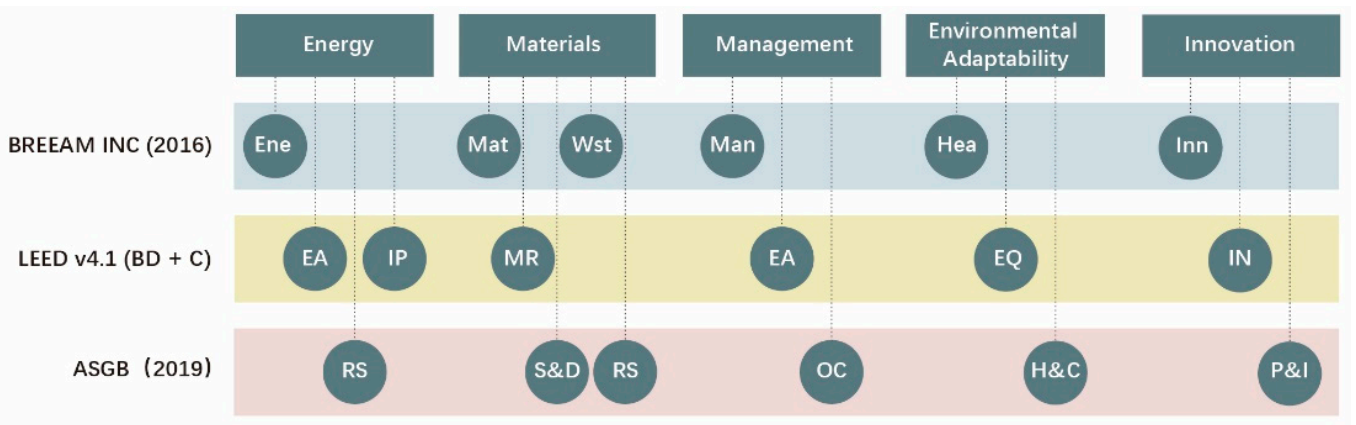

Figure 2. Scopes of related indicators.

\subsection{Analysis of Scope Weights of Related Indicators}

The analysis of the scope has clarified the fields that need to be involved in the BIPV low-carbon design, while it has not given priority among the scopes. The emphasis of each scope could be considered through an analysis of the scope weights.

In terms of the involved indicators related to BIPV carbon emission control in the energy scope, BREEAM INC 2016 mainly contains 'Energy-efficient design features (10 credits)' of Reduction of energy use and carbon emissions (Ene 01) and 'Passive design (2 credits)' and 'Low or zero-carbon technologies (1 credit)' of Low carbon design (Ene 04); the total credits of the energy category are 34 , and the category weight is $15 \%$, according to Equation (4). The energy scope weight $\left(B_{B R E E A M}^{\text {Energy }}\right)$ is $5.74 \%$. LEEDv4.1 BD + C mainly contains Evaluation and analysis of energy-related systems (1 credit) of IP, Optimise Energy Performance (18 credits) of EA, Grid Harmonization ( 2 credits) of EA, and Renewable Energy ( 5 credits) of EA, which is 26 in total. The total credits of LEED are 110, and the energy scope weight $\left(B_{L E E D}^{\text {Energy }}\right)$ is $23.64 \%$ according to Equation (5). ASGB-2019 mainly contains 7.2.4 Thermal performance of envelope structure ( 15 credits) and 7.2.9 Renewable energy (10 credits), which comprise 25 credits in total; based on Equation (6), the energy scope weight $\left(B_{A S G B}^{\text {Energy }}\right)$ is $3.57 \%$.

In terms of the indicators related to BIPV low-carbon design involved in the material scope, BREEAM INC 2016 mainly contains material category and waste category. Specifically, Life cycle impacts (Mat 01) have five credits, Responsible sourcing of construction products (Mat 03) achieves 3 credits, Designing for durability and resilience (Mat 05) achieves 1 credit, Material efficiency (Mat 06) achieves 1, and the total credits of the Mat category are 12, the category weight is $14.5 \%$, and according to Equation (4), the Mat category weight is $12.08 \%$. Adaption to climate change (Wst 05) achieves 1 credit, Functional adaptability (Wst 06) achieves 1 credit, and the total credits of the Wst category are 10 , the category weight is $9.5 \%$, and according to Equation (4), the Wst category weight is $1.90 \%$. Thus, the material scope weight $\left(B_{B R E E A M}^{\text {Material }}\right)$ is $13.98 \%$. LEEDv4.1 BD + C mainly contains building life-cycle impact reduction (4 credits) of MR and environmental product declarations (1 credit) of MR, the total credits of LEED are 110, and according to Equation (5), the material scope weight $\left(B_{L E E D}^{\text {Material }}\right)$ is $4.55 \%$. ASGB-2019 mainly contains 
4.2.6 Adaptability measures (7 credits), 4.2.7 Durability measures (10 credits) and 7.2.15 Reasonable selection of materials (10 credits), and based on Equation (6), the material scope weight $\left(B_{A S G B}^{\text {Material }}\right)$ is $3.86 \%$.

Regarding the indicators related to BIPV low-carbon design involved in management scope, BREEAM INC 2016 mainly contains the management and energy categories. Project brief and design (Man 01) achieves 2 credits, Responsible construction practices (Man 03) achieve 6 credits, Commissioning and handover (Man 04) contain 4 credits, Aftercare (Man 05) achieves 3 credits, and the total credits of the Man category are 21, with a category weight of $11 \%$; and according to Equation (4), the Man category weight is $7.86 \%$. Energy monitoring (Ene 02a) achieves 1 credit, and the total credits of Energy category are 34, with a category weight of $15 \%$, and according to Equation (4), the Ene category weight is $0.44 \%$; thus, the management scope weight $\left(B_{B R E E A M}^{\text {Management }}\right)$ is $8.30 \%$. LEEDv4.1 $\mathrm{BD}+\mathrm{C}$ mainly contains enhanced commissioning (6 credits) of EA, and advanced energy metering (1 credits) of EA, and according to Equation (5), the management scope weight $\left(B_{\text {LEED }}^{\text {Management }}\right)$ is $6.36 \%$. ASGB-2019 mainly contains 6.2.6 Energy management, metering system (8 credits) and 6.2.12 Operational effect evaluation (10 credits), and according to Equation (6), the management scope weight $\left(B_{A S G B}^{\text {Management }}\right)$ is $2.57 \%$.

In terms of the indicators related to BIPV low-carbon design involved in the environmental adaptability scope, BREEAM INC 2016 mainly contains indoor air quality (Hea 02) of Health and Well-being, which accounts for 1 credit and the total credits of Hea category are 25 , with a category weight is $10.5 \%$, and according to Equation (4), the environmental adaptability scope weight $\left(B_{B R E E A M}^{\text {Environmental }}\right)$ is $0.42 \%$. LEEDv4.1 BD $+C$ mainly contains enhanced indoor air quality strategies (1 credit) of EQ, and according to Equation (5), the environmental adaptability scope weight $\left(B_{L E E D}^{\text {Environmental }}\right)$ is $0.91 \%$. ASGB-2019 mainly contains 5.2.10 Natural ventilation (8 credits) and 5.2.11 Shading facilities ( 9 credits). According to Equation (6), the environmental adaptability scope weight $\left(B_{A S G B}^{\text {Environmental }}\right)$ is $2.43 \%$.

In terms of the indicators related to BIPV low-carbon design involved in the innovation scope, BREEAM INC 2016 mainly contains innovation (Inn 01) of Innovation, which accounts for 10 credits; the total credits of the Inn category are 10, with a category weight of $10 \%$, and according to Equation (4), the innovation scope weight $\left(B_{B R E E A M}^{\operatorname{Innovation}}\right)$ is $10 \%$. LEEDv4.1 BD + C mainly contains innovation (five credits) of IN, and according to Equation (5), the innovation scope weight $\left(B_{L E E D}^{\text {Innovation }}\right)$ is $4.55 \%$. ASGB-2019 mainly contains 9.2.5 Industrialization construction (10 credits) and 9.2.7 Carbon emission calculation (12 credits), and according to Equation (6), the innovation scope weight $\left(B_{A S G B}^{\text {Innovation }}\right)$ is $3.14 \%$.

A comparison of the five scope weights is shown in Figure 3. In terms of the energy scope weights, $B_{L E E D}^{\text {Energy }}(23.64 \%)>B_{B R E E A M}^{\text {Energy }}(5.74 \%)>B_{A S G B}^{\text {Energy }}(3.57 \%)$, and the average energy scope weight $\left(B_{\text {Average }}^{\text {Energy }}\right)$ was $10.98 \%$. In terms of the material scope weights, $B_{B R E E A M}^{\text {Material }}(13.98 \%)>B_{L E E D}^{\text {Material }}(4.55 \%)>B_{A S G B}^{\text {Material }}(3.86 \%)$, and the average material scope weight $\left(B_{\text {Average }}^{\text {Material }}\right)$ was $7.46 \%$. In terms of management scope weights, $B_{B R E E A M}^{\text {Management }}$ $(8.30 \%)>B_{L E E D}^{\text {Management }}(6.36 \%)>B_{A S G B}^{\text {Management }}(2.57 \%)$, and the average management scope weight $\left(B_{\text {Average }}^{\text {Managent }}\right)$ is $5.74 \%$. In terms of environmental adaptability scope weights, $B_{A S G B}^{\text {Environmental }}(2.43 \%)>B_{\text {LEED }}^{\text {Environmental }}(0.91 \%)>B_{B R E E A M}^{\text {Environmental }}(0.42 \%)$, and the average environmental adaptability scope weight $\left(B_{\text {Average }}^{\text {Environtal }}\right)$ was $1.25 \%$. In terms of innovation scope weights, $B_{B R E E A M}^{\text {Innovation }}(10 \%)>B_{L E E D}^{\text {Innovation }}(4.55 \%)>B_{A S G B}^{\text {Innovation }}(3.14 \%)$, and the average innovation scope weight $\left(B_{\text {Average }}^{\text {Innovation }}\right)$ is $5.90 \%$. Comparing the average scope weights, $B_{\text {Average }}^{\text {Envergy }}(10.98 \%)>B_{\text {Average }}^{\text {Material }}(7.46 \%)>B_{\text {Average }}^{\text {Innovation }}(5.90 \%)>B_{\text {Average }}^{\text {Management }}(5.74 \%)>B_{\text {Average }}^{\text {Environmental }}$ $(1.25 \%)$, which shows that energy and material scopes should be considered mainly in BIPV low-carbon design. 


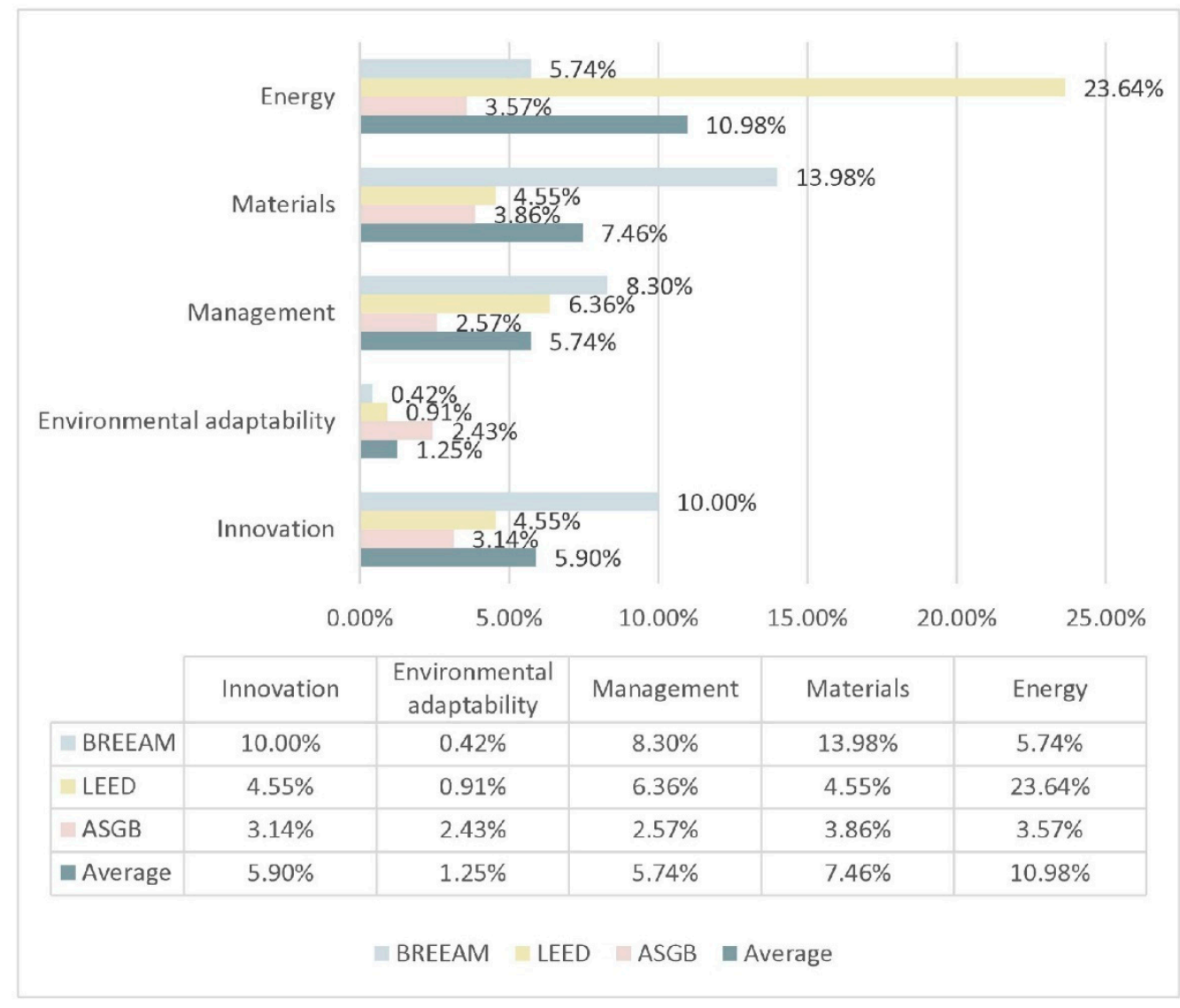

Figure 3. Analysis of scope weights.

\subsection{Analysis of Induction of Measures Related to BIPV Low Carbon Design}

The scope of the BIPV low-carbon design is clear, and the measures of each scope should be summarised. There are commonalities and differences in measures related to BIPV low-carbon design in the five scopes. In the energy scope, 7.2.9 Renewable energy in ASGB-2019, Ene 04 in BREEAM INC 2016, and renewable Energy of EA in LEEDv4.1 $\mathrm{BD}+\mathrm{C}$ could be summarized as 'Renewable energy', which is applicable to BIPV that mainly uses solar energy. All three GBRS suggest a quantitative requirement for the renewable energy utilisation ratio. Ene 01 in BREEAM INC 2016 and Optimize Energy Performance of EA in LEEDv4.1 BD + C can be summarised as 'optimise energy performance'. Grid Harmonization of EA in LEEDv4.1 BD + C can be regarded as 'grid harmonisation'. Evaluation and analysis of energy-related systems of IP in LEEDv4.1 BD + C could be regarded as 'energy system assessment'. In the material scope, 7.1.10 Building materials selection compliance in ASGB-2019, Responsible sourcing of construction products of Mat 03 in BREEAM INC 2016, and Environmental Product Declarations of MR in LEEDv4.1 $\mathrm{BD}+\mathrm{C}$ could be summarised as 'reliability procurement'. 4.2.6 Adaptability measures in ASGB-2019 and Wst 05 and Wst 06 in BREEAM INC 2016 could be summarised as 'adaptability measures'. 4.1.2 Enclosure structure safe and durable protection, 4.1.3 Unified design and construction of external facilities and buildings, 4.1.4 The components are firmly connected, 4.1.5 The doors and windows are firm, and the pressure resistance and water tightness are compliant, and 4.2.7 Durability measures in ASGB-2019 and Mat 05 in BREEAM INC 2016 could be summarized as 'durability measures'. Mat 01 in BREEAM INC 2016 and Building Life-Cycle Impact Reduction of MR in LEEDv4.1 BD + C can be summarised as 'life cycle assessment'. Mat 06 in BREEAM INC 2016 can be regarded as 'material efficiency'.

In the management scope, 6.2.6 Energy management, metering system in ASGB-2019, energy monitoring of Ene 02a in BREEAM INC 2016, and building-level energy metering 
fundamental refrigerant and advanced energy metering of EA in LEEDv4.1 BD + C could be summarised as 'energy management and metering system'. Man 04 in BREEAM INC 2016, and fundamental commissioning and verification of MR and enhanced commissioning of EA in LEEDv4.1 BD + C could be summarised as 'commissioning'. Man 05 in BREEAM INC 2016 could be regarded as 'maintenance service'. In the environmental adaptability scope, 5.2.10 Natural ventilation in ASGB-2019, the potential for ventilation of Hea 02 in BREEAM INC 2016, and ventilation strategy of enhanced indoor air quality strategies in LEEDv4.1 $\mathrm{BD}+\mathrm{C}$ could be summarised as 'ventilation measures'. 5.2.11 Shading facilities in ASGB2019 could be regarded as 'shading measures'. 5.1.7 Thermal performance compliance of the envelope structure and 7.2.4 Thermal performance of the envelope structure in ASGB-2019 can be summarised as 'thermal engineering of the envelope structure'.

In the innovation scope, LEEDv4.1 BD $+\mathrm{C}$ mentions the promotion of innovation. While there is a lack of specific regulations, and ASGB-2019 has two main innovation indicators related to BIPV low carbon design, which are 9.2.5 Industrialization construction regarded as 'industrialisation construction' and 9.2.7 Carbon emission calculation regarded as 'carbon emission calculation'. BREEAM INC 2016 also mentions the carbon emission calculation, which encourages the use of related certified software. In summary, there are 17 measures of BIPV low-carbon design inducted in five scopes, as shown in Table 4 .

Table 4. The induction of 17 measures within five scopes.

\begin{tabular}{|c|c|c|c|c|c|}
\hline Scopes & Energy & Material & Management & Environmental Adaptability & Innovation \\
\hline \multirow{5}{*}{ Measures } & $\begin{array}{c}\text { Renewable energy } \\
\square \square\end{array}$ & $\begin{array}{l}\text { Reliability } \\
\text { procurement }\end{array}$ & $\begin{array}{l}\text { Energy management } \\
\text { and metering system }\end{array}$ & $\begin{array}{c}\text { Ventilation measures } \\
\qquad \square\end{array}$ & $\begin{array}{l}\text { Carbon emission } \\
\text { calculation }\end{array}$ \\
\hline & $\begin{array}{c}\text { Optimize Energy } \\
\text { Performance } \\
\square\end{array}$ & $\begin{array}{l}\text { Adaptability } \\
\text { measures }\end{array}$ & Commissioning & $\begin{array}{c}\text { Shading measures } \\
\bigcirc\end{array}$ & $\begin{array}{c}\text { Industrialization } \\
\text { construction } \\
\bigcirc\end{array}$ \\
\hline & $\begin{array}{c}\text { Grid Harmonization } \\
\square\end{array}$ & Durability measures & Maintenance service & $\begin{array}{c}\text { Thermal performance } \\
\text { optimization of building } \\
\text { envelope } \\
\end{array}$ & \\
\hline & \multirow[t]{2}{*}{$\begin{array}{c}\text { Energy system } \\
\text { assessment } \\
\square\end{array}$} & $\begin{array}{c}\text { Life cycle assessment } \\
\square \square\end{array}$ & & & \\
\hline & & Material efficiency & & & \\
\hline
\end{tabular}

Note: $\bigcirc:$ ASGB; $\diamond$ : BREEAM; $\square:$ LEED.

\subsection{Analysis of Features of the Measures}

\subsubsection{Implementation from Different Stages}

According to the GBRS, different indicators have different implementation stages. All stages should be considered in the low-carbon design of the BIPV. From the five scopes, BREEAM and LEED are highly consistent in terms of the coverage of the evaluation stages in the same scope: the material scope involves all stages of buildings, which are the design, construction, operation, and demolition stages. The energy scope and management scope all involve the design, construction, and operation stages. ASGB mainly involves the evaluation of the design and operation stages, while the carbon emission calculation in the innovation scope requires all the stages of buildings. The implementation from the different stages is shown in Figure 4.

\subsubsection{Necessary and Recommended Ones}

Because the 17 measures are the induction of relevant indicators in the three GBRS. The measures contain the properties of control items and scoring items, in which control items are mandatory requirements. As an essential type of green building technology, the BIPV low-carbon design must meet the necessary requirements. Seven of the 17 measures are regarded as the necessary low-carbon design of BIPV, which are durability measures, thermal performance optimisation of building envelope, reliability procurement, commis- 
sioning, energy management and metering system, maintenance service, and optimised energy performance. Ten of 17 recommended design measures, including renewable energy, ventilation measures, adaptability measures, life cycle assessment, shading measures, industrialisation construction, carbon emission calculation, material efficiency, grid harmonisation, and energy system assessment (Figure 5).

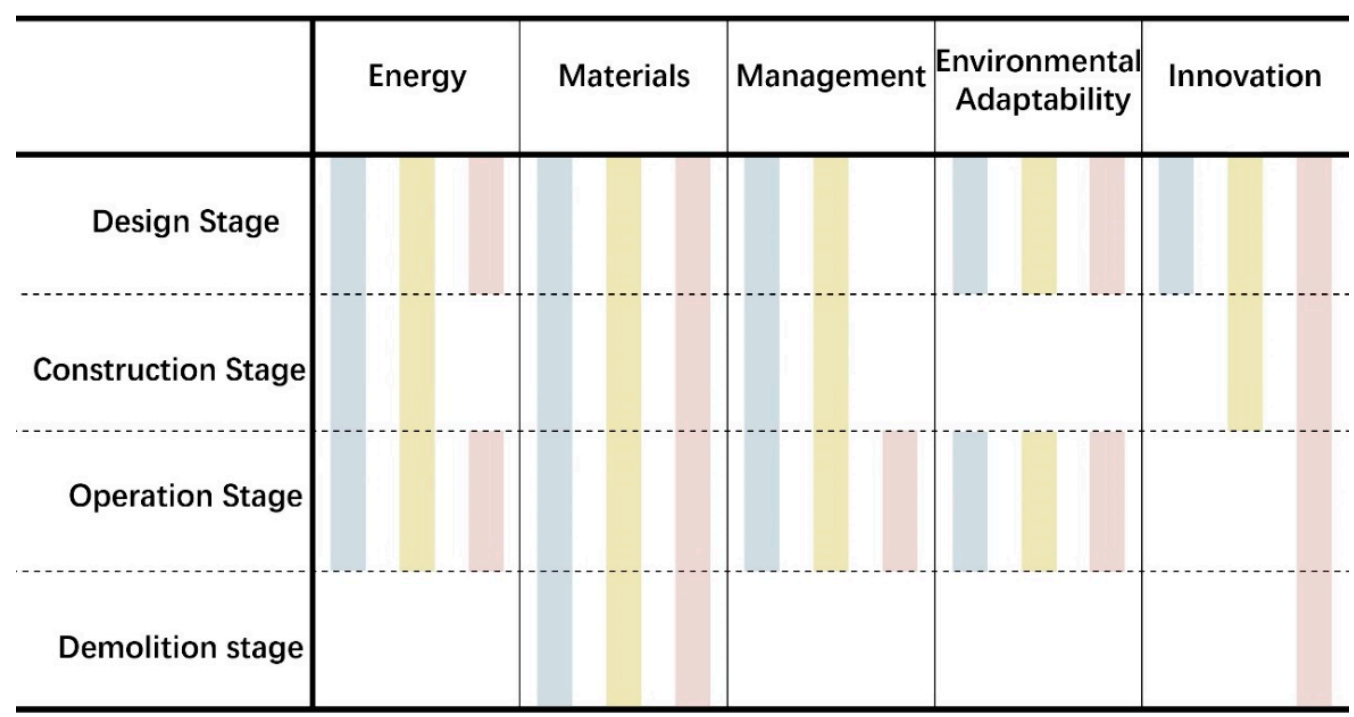

BREEAM

LEED

ASGB

Figure 4. Implementation Involving Different Stages.

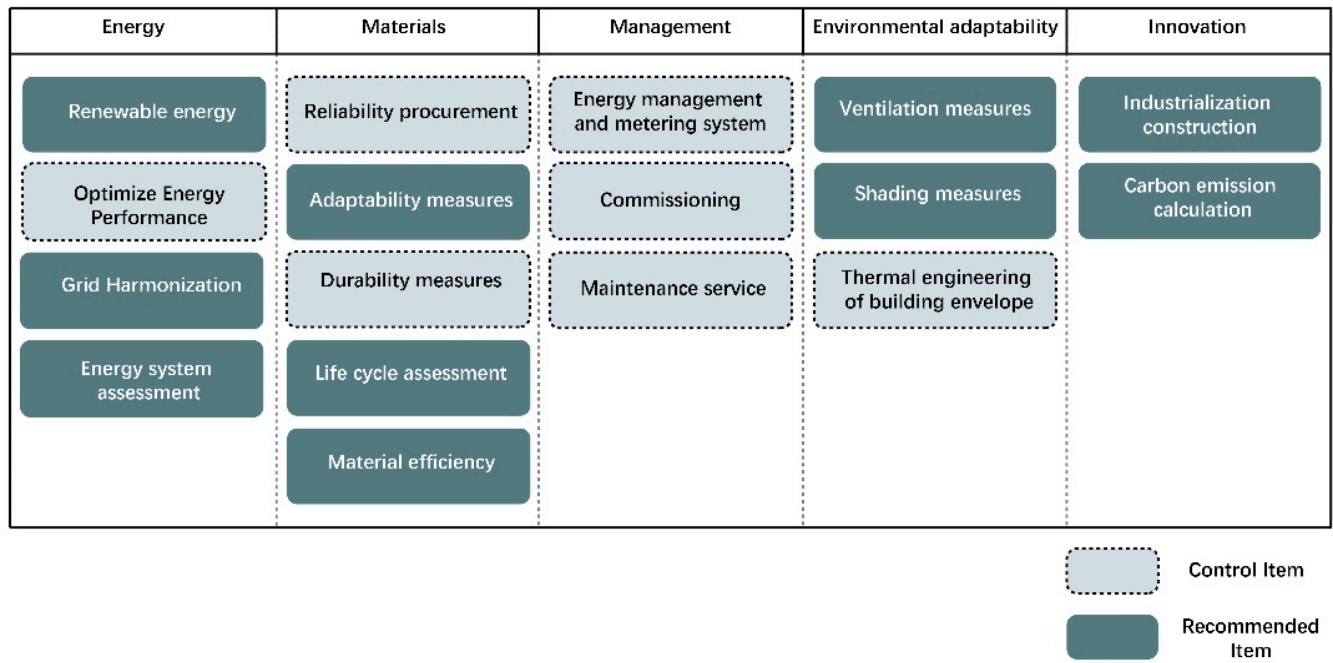

Figure 5. Control and recommended items of measures.

\section{Discussion}

Based on the five scopes and 17 measures, we proposed a low-carbon design path for BIPV (Figure 6). There are six main contents involving five aspects. In terms of energy scope, a new building energy system should be designed, including energy system assessment, grid harmonization, and optimal energy performance. In terms of material scope, material use should be optimized in reliability procurement, adaptability, durability, life cycle assessment, and efficiency of materials. In terms of management scope, the design 
considering the management contains commissioning, maintenance service, and energy management and metering system.

Regarding environmental adaptability scope, it is essential to combine the active with the passive design mainly in ventilation, shading, and thermal engineering of building envelope. In terms of innovation scope, the design should be based on carbon emission values, which carbon emission calculation should be necessary, and the innovation is important to enhancing the efficiency like industrialization construction. It is suggested that all five scopes should be considered at the beginning of the low-carbon design synthetically.

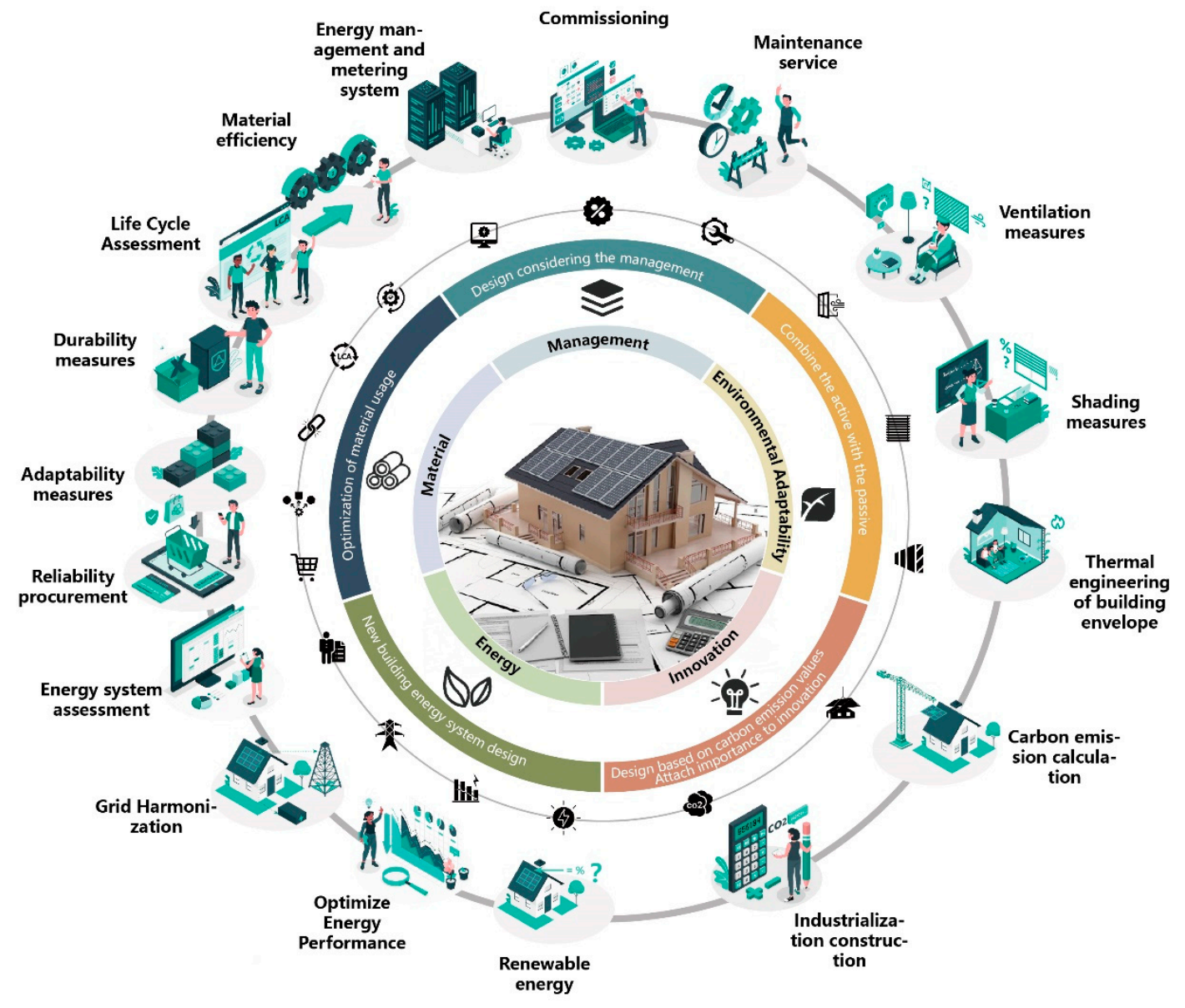

Figure 6. The low-carbon design path of BIPV.

\subsection{New Building Energy System Design}

In contrast to conventional buildings, which mainly consume fossil energy, BIPV reduces carbon emissions by increasing solar energy to replace fossil fuels. Therefore, a new building energy system design should be considered a priority. According to the measures of energy, the utilisation ratio of solar energy should be increased, and a reasonable configuration of the BIPV system should be designed according to the standard of the utilisation ratio of solar energy. Design to optimise energy performance helps reduce the energy consumption and carbon emissions of buildings, and during the design process, energy simulation tools can be used to verify the specific effect of system optimisation [46]. At the same time, the BIPV energy system design should emphasise coordination with the power grid to make the energy production and distribution system more economical and effective. The coordination of the power grid in the design needs to carry out demand analysis of the building, and then rationally allocate the power system in combination with the demand to achieve power self-absorption and demand response. If the power generated by the BIPV cannot be absorbed by itself, energy storage facilities can be considered for 
better grid coordination $[47,48]$. It is essential that the energy system be evaluated in the early stage, including site condition, volume and direction, and envelope properties, to clarify the restrictions and favourable conditions of BIPV low-carbon design and improve the adaptability and efficiency of the system design.

\subsection{Optimization of Material Usage}

The materials of photovoltaic modules are different from those of general building envelope materials. BIPV contains various components, and the quality of the components cannot be guaranteed because of the lack of authoritative specification constraints. Reliability procurement should be considered in the design process. Reliability procurement encourages local sources, and purchasing local building materials is an important means to reduce the consumption of resources and energy during material transportation. The design should first select materials produced within $500 \mathrm{~km}$ [49]. High-quality, standardised, and assembled BIPV component materials are prioritised to reduce the material waste indirectly resulting from nonconforming construction processes. Adaptability usage helps the BIPV system better adapt to the changes in building functions, avoiding the problem of replacing facilities resulting from the mismatching of environment and function.

The separation of equipment pipelines and damage resistance assessment of materials could be an effective approach to meet adaptability. Durability optimisation is helpful in reducing the replacement times of parts and achieving the purpose of material saving. Because the service life of the building envelope is not consistent with the main structure of the building, the BIPV envelope needs to solve the maintenance and replacement problems, and choosing high durability materials could reduce the requirement for replacement of parts [50]. The material life cycle is the main consideration in design as LCA helps determine the characteristics of the life cycle of different materials and achieves savings by using materials with long life cycles. Simply reducing the number of materials cannot meet the growing demand of buildings, and the purpose of low carbon from materials could be better achieved by improving the efficiency of material usage. Solar panels of different materials have various conversion efficiencies; the conversion efficiency of monocrystalline silicon is $15-20 \%$, that of polycrystalline silicon is $12-17.8 \%$, and that of amorphous silicon is $5-14 \%$ [51]. Different materials of solar panels have different conversion efficiency, which is one of the main equipment factors affecting the conversion efficiency of solar energy by photovoltaic panels. Photovoltaic system generates a certain amount of electricity through solar energy to replace the electricity generated by thermal power generation, so as to reduce the use of fossil energy and reduce $\mathrm{CO}_{2}$ emissions. Other things being equal, the higher the conversion efficiency of the photovoltaic system, the more obvious its power generation capacity and emission reduction effect. From the theoretical value, monocrystalline silicon is a more suitable material for optimizing solar panel efficiency.

\subsection{Design Based on Carbon Emission Values}

To judge the effectiveness of building a low-carbon design, it is necessary to conduct a quantitative analysis of the carbon emission indicators. The BIPV low-carbon design should be an effect-oriented design based on the carbon emission values. BREEAM and ASGB require carbon emission calculations to some extent. In the design stage, the building $\mathrm{CO}_{2}$ emission rate could be forecasted based on certified consumption calculation software, and the calculation approach could refer to the national standard GB/T 51366-2019 [49]. At present, the more recognised calculation method logic is by multiplying the quantities of resources by the $\mathrm{CO}_{2}$ emission unit for each resource. The $\mathrm{CO}_{2}$ emissions in the building lifecycle were calculated using Equation (7):

$$
C_{L C A}=C_{m}+C_{c}+C_{o}+C_{d}
$$

where $C_{L C A}$ is the total $\mathrm{CO}_{2}$ emissions of the building lifecycle, $C_{m}$ is the $\mathrm{CO}_{2}$ emission of the material during the production and transportation stage, $\mathrm{C}_{c}$ is the $\mathrm{CO}_{2}$ emission during 
the construction stage, $C_{o}$ is the $\mathrm{CO}_{2}$ emission during the operation stage, and $C_{d}$ is the $\mathrm{CO}_{2}$ emission during the demolition stage.

Though the design is in the early stage, the carbon emission values should be considered in the whole life cycle of a building. Through empirical prediction and scientific simulation, carbon emissions at different stages of a building can be calculated to achieve targeted optimization of a low-carbon design.

\subsection{Design Considering the Management}

To achieve carbon emission reduction in the building life cycle, the design phase can provide support conditions for achieving reasonable management. In modern buildings, a building management system (BMS) is installed to monitor the operation data and optimise the operational efficiency of building systems [52]. Building intelligence can effectively help users manage energy-saving and low-carbon operations. The metering system is the basic condition for realising operation energy saving and optimising the system setting. The energy management system makes building energy consumption knowable, visible, and controllable to optimize the operation and reduce consumption. Through the design of an intelligent energy monitoring platform, photovoltaic data can be collected, dynamic tracking, automatic control of operation and maintenance, and remote monitoring can be performed. With the popularity of photovoltaic power generation, building design must consider how to ensure the security of the solar such "intermittent energy" into the power grid; the smart grid system combines the advanced sensor measurement technology, communication technology, information technology, computer technology and control technology with the physical power grid together to meet users' optimal power allocation, ensure the safety and reliability of power supply.

In the design, a smart electricity meter is used to replace a traditional mechanical electricity meter to realize the selective power consumption of users at different times. For instance, the internet of things (IoT) could be used to automatically adjust the balance of the use of electricity between the external grid and photovoltaic power of a building following by the variations of solar illuminance and building power load. Intelligent management designs related to the low carbon operation of BIPV include intelligent monitoring system design of BIPV, design of indoor temperature intelligent control systems, design of lighting and shading intelligent systems, and design of intelligent facades of BIPV. Commissioning should also be focused on design, and system commissioning affects the performance and durability of BIPV systems. The commissioning in BIPV low-carbon design mainly considers the commissioning scheme of the BIPV system at a later stage and clarifies the purpose, demand, content, and process [53]. Considering maintenance services, the convenience of maintenance and protection in the later period should be considered in BIPV low-carbon design, with specific measures such as reserved access for maintenance and pedal-able design.

\subsection{Combine the Active with the Passive}

The environmental adaptability of the BIPV building depends not only on the support of BIPV active technology but also on the passive designs of the building itself. Specifically, natural ventilation strategies can reduce the dependence on mechanical ventilation, which has a significant impact on the performance of BIPV systems. In the low-carbon design of BIPV, the location of photovoltaic panels, opening mode of wind vents, and structure of BIPV components should be considered. For instance, on the windward side of the dominant wind direction in summer, photovoltaic panels are set up as inward notches to facilitate the wind pressure difference of natural ventilation and to better introduce natural wind. Regarded as the shading envelop, the area proportion of adjustable shading facilities and the combination of BIPV and shading should be considered to control the indoor temperature and reduce air conditioning energy consumption effectively. For instance, photovoltaic panels are reasonably set in the parts with strong western sun exposure, which not only realizes self-shading, reducing the demand for indoor refrigeration but also 
rationally uses solar radiation to increase photovoltaic power generation effect. Improving the performance of the building envelope is an energy-saving method for the building itself; it can reduce the building's cooling and heating load demand. The thermal performance optimisation of the envelope structure in a BIPV low-carbon design can be realised through the optimisation of the U value, air tightness, heat insulation, and other indicators $[54,55]$.

\subsection{Attach Importance to Innovation}

BIPV is one of the important ways to achieve carbon neutrality of buildings, and its development process requires the cooperation of architecture and other subject areas. Compared with traditional building design, which mainly requires architectural skills, BIPV low-carbon design requires more interdisciplinary training, and there will be more innovative designs. For instance, the CIGS-BIPV display unit adopts the unit CIGS intelligent envelope structure to complete the rapid and efficient construction by using the construction method of integral fabrication and achieves self-supply of building energy consumption. Through the application and regulation of new energy and other technical measures, the self-supply of building energy consumption can be realised [56], and as a new type of energy material, thin-film solar cells that have high plasticity and ductility, can be combined with aesthetic art and low-carbon environmental protection in different parts of the building envelopes [57].

\section{Conclusions}

The main findings of this study regarding BIPV low-carbon design based on the GBRS comparative analysis are as follows:

1. There are five scopes of indicators related to BIPV $\mathrm{CO}_{2}$ emission control: which are Energy, Materials, Management, Environmental adaptability, and Innovation.

2. Although the scope weights in the three GBRS are varied, they all have convergence laws, in which scopes of energy and material should be considered mainly in BIPV low-carbon design. The average scope weights from large to small are: the average energy scope weight $(10.98 \%)$, the average material scope weight $(7.46 \%)$, the average innovation scope weight $(5.90 \%)$, the average management scope weight $(5.74 \%)$, and the average environmental adaptability scope weight (1.25\%).

3. There are 17 measures of BIPV low-carbon design inducted in five scopes. Among them, seven measures are necessary, and 10 are recommended for the low-carbon design of BIPV.

4. This study proposed a low-carbon design path for BIPV. Based on the features of $\mathrm{BIPV}$, the low-carbon design path of BIPV should pay more attention to six aspects: new building energy system design, optimisation of material usage, design based on carbon emission values, design considering the management, combining the BIPV technology with passive measures, and attaching importance to innovation.

This study provides theoretical and methodological guidance for the low-carbon design of BIPV buildings. The outcomes are mainly derived from the comparative analysis of related indicators of the three GBRS, mainly involving the realisation of carbon emission reduction from the parts of building energy and resource consumption. In the future, continuous research could be conducted from another important part of carbon neutrality, which is the carbon sink of buildings. The research plan of carbon sink will carry out integrated design from vertical planting and reasonable arrangement of photovoltaic panels, and discuss the influencing factors of carbon sink under integrated design and the realization of the building zero-carbon goal.

Author Contributions: Conceptualization, K.L.; Data curation, B.Z.; Formal analysis, K.L. and B.Z.; Funding acquisition, J.C.; Investigation, B.Z.; Methodology, K.L.; Project administration, K.L.; Resources, J.C.; Software, B.Z.; Supervision, K.L. and J.C.; Validation, K.L. and J.C.; Visualization, B.Z.; Writing-original draft, K.L. and B.Z.; Writing-review \& editing, K.L. and B.Z. All authors have read and agreed to the published version of the manuscript. 
Funding: This research was funded by National Natural Science Foundation of China, 62072324 and Suzhou University of Science and Technology Research projects funding for the introducing talents, 332111304 .

Data Availability Statement: Not applicable.

Acknowledgments: The author gratefully acknowledges the editors and referees for their positive and constructive comments in the review process.

Conflicts of Interest: The authors declare no conflict of interest.

\section{References}

1. Pokhrel, S.R.; Hewage, K.; Chhipi-Shrestha, G.; Karunathilake, H.; Sadiq, R. Carbon Capturing for Emissions Reduction at Building Level: A Market Assessment from a Building Management Perspective. J. Clean. Prod. 2021, 294, 126323. [CrossRef]

2. Global Carbon Atlas 2019. Available online: http:/ /www.globalcarbonatlas.org/en/CO2-emissions (accessed on 6 May 2021).

3. Xi Jinping Delivered an Important Speech at the General Debate of the Seventy-Fifth United Nations General Assembly. Available online: http:/ / www.xinhuanet.com/politics/leaders/2020-09/22/__1126527652.htm (accessed on 4 May 2020).

4. Mata, É.; Korpal, A.K.; Cheng, S.H.; Jiménez Navarro, J.P.; Filippidou, F.; Reyna, J.; Wang, R. A map of roadmaps for zero and low energy and carbon buildings worldwide. Environ. Res. Lett. 2020, 15, 113003. [CrossRef]

5. Cai, W. Research Report on Building Energy Consumption in China; China Building Energy Conservation Association: Xiamen, China, 2020.

6. Jega, B.; Tvha, C.; Dsa, B. A physics-based high-resolution BIPV model for building performance simulations. Sol. Energy 2020, 204, 585-599.

7. Atănăsoae, P.; Pentiuc, R.D. Choosing the Energy Sources Needed for Utilities in the Design and Refurbishment of Buildings. Buildings 2018, 8, 54. [CrossRef]

8. Osseweijer, F.; Van Den Hurk, L.B.; Teunissen, E.J.; van Sark, W.G.J.H.M. A comparative review of building integrated photovoltaics ecosystems in selected European countries. Renew. Sustain. Energy Rev. 2018, 90, 1027-1040. [CrossRef]

9. International Energy Agency. Snapshot of Global Photovoltaic Markets; Report IEA PVPS T1-26:2015; International Energy Agency: Paris, France, 2015.

10. International Organization for Standardization. Glass in building_Laminated Solar Photovoltaic Glass for Use in Building; ISO/FDIS 18178:2016; International Organization for Standardization: Geneva, Switzerland, 2016.

11. International Electrotechnical Commission. Photovoltaic (PV) Module Safety Qualification; IEC 61730-1:2016; International Electrotechnical Committee: Geneva, Switzerland, 2016.

12. Energy Technology Committee. Building Integrated Photovoltaics (BIPV) Modules—The Requirement of Performance Evaluation; KS C 8577; Korean Standards Association: Seoul, Korea, 2016.

13. IEA PVPS Task 15. International Definitions of "BIPV". Available online: https://iea-pvps.org/wp-content/uploads/2020/02/ IEA-PVPS_Task_15_Report_C0_International_definitions_of_BIPV_hrw_180823.pdf (accessed on 26 July 2021).

14. Si-Meng, L.I. Integrated Design Strategy of PV and Building Skin. Build. Energy Effic. 2018, 46, 84-87, 106.

15. Jeon, H.; Choi, K.H.; Lee, S.; Park, S. Development of BIM based BIPV Architectural Design Environment. KIEAE J. 2018, 18, 71-82. [CrossRef]

16. Yoo, S.H. Optimization of a BIPV system to mitigate greenhouse gas and indoor environment. Sol. Energy 2019, 188, 875-882. [CrossRef]

17. Roy, A.; Ghosh, A.; Bhandari, S.; Sundaram, S.; Mallick, T.K. Perovskite Solar Cells for BIPV Application: A Review. Buildings 2020, 10, 129. [CrossRef]

18. Park, J.; Hengevoss, D.; Wittkopf, S. Industrial Data-Based Life Cycle Assessment of Architecturally Integrated Glass-Glass Photovoltaics. Buildings 2019, 9, 8. [CrossRef]

19. Schregle, R.; Renken, C.; Wittkopf, S. Spatio-Temporal Visualisation of Reflections from Building Integrated Photovoltaics. Buildings 2018, 8, 101. [CrossRef]

20. Yang, S.; Fiorito, F.; Prasad, D.; Sproul, A.; Cannavale, A. A sensitivity analysis of design parameters of BIPV/T-DSF in relation to building energy and thermal comfort performances. J. Build. Eng. 2021, 41, 102426. [CrossRef]

21. Yang, S.; Cannavale, A.; Carlo, A.D.; Prasad, D.K.; Fiorito, F. Performance assessment of BIPV/T double-skin faade for various climate zones in Australia: Effects on energy consumption. Sol. Energy 2020, 199, 377-399. [CrossRef]

22. Skandalos, N.; Karamanis, D. Investigation of thermal performance of semi-transparent PV technologies. Energy Build. 2016, 124, 19-34. [CrossRef]

23. Sozer, H.; Elnimeiri, M. Identification of Barriers to PV Application into the Building Design. In Proceedings of the ASME 2003 International Solar Energy Conference, Kohala Coast, HI, USA, 15-18 March 2003.

24. Chemisana, D. Building Integrated Concentrating Photovoltaics: A review. Renew. Sustain. Energy Rev. 2011, 15, 603-611. [CrossRef]

25. Parisi, A.; Pernice, R.; Andò, A.; Cino, A.C.; Franzitta, V.; Busacca, A.C. Electro-optical characterization of ruthenium-based dye sensitized solar cells: A study of light soaking, ageing and temperature effects. Optik 2017, 135, 227-237. [CrossRef] 
26. Ming, L.; Yong, L.; Hai, W.; Shen, H. Synthesis of $\mathrm{TiO}_{2}$ submicro-rings and their application in dye-sensitized solar cell. Appl. Energy 2011, 88, 825-830.

27. Haghighi, Z.; Angali Dehnavi, M.; Konstantinou, T.; van den Dobbelsteen, A.; Klein, T. Architectural Photovoltaic Applications: Lessons Learnt and Perceptions from Architects. Buildings 2021, 11, 62. [CrossRef]

28. Peng, C.; Huang, Y.; Wu, Z. Building-integrated photovoltaics (BIPV) in architectural design in China. Energy Build. 2011, 43, 3592-3598. [CrossRef]

29. Hong, T.H.; Kim, H.J.; Kwak, T.H. Energy-Saving Techniques for Reducing Emissions in Elementary Schools. J. Manag. Eng. 2012, 28, 39-50. [CrossRef]

30. Liu, K.; Leng, J. Quantified $\mathrm{CO}_{2}$-related indicators for green building rating systems in China. Indoor Built. Environ. 2021, 30, 763-776. [CrossRef]

31. Remizov, A.; Tukaziban, A.; Yelzhanova, Z.; Junussova, T.; Karaca, F. Adoption of Green Building Assessment Systems to Existing Buildings under Kazakhstani Conditions. Buildings 2021, 11, 325. [CrossRef]

32. Tecnalia-Icares. BIP Boost: Update on BIPV Market and Stakeholder Analysis; The European Commission: Brussels, Belgium, 2019.

33. Prasad, D.K.; Snow, M. Designing with Solar Power: A Source Book for Building Integrated Photovoltaics (BIPV); The Images Publishing Group Pty Ltd. and Earthscan: London, UK, 2005.

34. Matic, D.; Calzada, J.R.; Todorovic, M.S. Renewable energy sources-integrated refurbishment approach for low-rise residential prefabricated building in Belgrade, Serbia. Indoor Built. Environ. 2016, 25, 1016-1023. [CrossRef]

35. Kylili, A.; Fokaides, P. Investigation of building integrated photovoltaics potential in achieving the zero energy building target. Indoor Built Environ. 2014, 3, 92-106. [CrossRef]

36. Hoseinzadeh, P.; Assadi, M.K.; Heidari, S.; Khalatbari, M.; Sangin, H. Energy Performance of Building Integrated Photovoltaic high-rise building: Case study, Tehran, Iran. Energy Build. 2021, 235, 110707. [CrossRef]

37. Gercek, C.; Devetakovi, M.; Krsti-Furundi, A.; Reinders, A. Energy Balance, Cost and Architectural Design Features of 24 Building Integrated Photovoltaic Projects Using a Modelling Approach. Appl. Sci. 2020, 10, 8860. [CrossRef]

38. He, Y.; Kvan, T.; Liu, M.; Li, B. How green building rating systems affect designing green. Build. Environ. 2018, 133, 19-31. [CrossRef]

39. BRE Global's Scheme Document SD233 2.0; BREEAM International New Construction: London, UK, 2016.

40. Leadership in Energy \& Environmental Design. Available online: https://www.usgbc.org/leed/rating-systems/new-buildings (accessed on 5 May 2021).

41. Michael, M.; Zhang, L.; Xia, X. An optimal model for a building retrofit with LEED standard as reference protocol. Energy Build. 2017, 139, 22-30. [CrossRef]

42. Feng, H.; Hewage, K. Energy saving performance of green vegetation on LEED certified buildings. Energy Build. 2014, 75, 281-289. [CrossRef]

43. Jeong, J.; Hong, T.; Ji, C.; Kim, J.; Lee, M.; Jeong, K. Development of an evaluation process for green and non-green buildings focused on energy performance of G-SEED and LEED. Build. Environ. 2016, 105, 172-184. [CrossRef]

44. Ministry of Housing and Urban-Rural Development of the People's Republic of China. Assessment Standard for Green Building GB/T 50378-2019; China Architecture \& Building Press: Beijing, China, 2019.

45. Ali, H.H.; Al Nsairat, S.F. Developing a green building assessment tool for developing countries-Case of Jordan. Build. Environ. 2009, 44, 1053-1064. [CrossRef]

46. Biyik, E.; Araz, M.; Hepbasli, A.; Shahrestani, M.; Yao, R.; Shao, L.; Essah, E.; Oliveira, A.; del Caño, T.; Rico, E.; et al. A key review of building integrated photovoltaic (BIPV) systems. Eng. Sci. Technol. Int. J. 2017, 20, 833-858. [CrossRef]

47. Rusen, A.M.; Tokar, D. Building Integrated Photovoltaics (BIPV). Rom. J. Civ. Eng. 2020, 11, 423-428.

48. Aelenei, D.; Lopes, R.A.; Aelenei, L.; Gonçalves, H. Investigating the potential for energy flexibility in an office building with a vertical BIPV and a PV roof system. Renew. Energy 2019, 137, 189-197. [CrossRef]

49. Ministry of Housing and Urban-Rural Development of the People's Republic of China. Standard for Building Carbon Emission Calculation GB/T 51366-2019; China Architecture \& Building Press: Beijing, China, 2019; pp. 7, 8, 14, 15, 18.

50. Jelle, B.P.; Breivik, C. The Path to the Building Integrated Photovoltaics of Tomorrow. Energy Procedia 2012, 20, 78-87. [CrossRef]

51. Liu, K. Study on Low-Carbon Design of High and Large Space Public Building in Hot-Summer and Cold-Winter Area of China; Southeast University: Nanjing, China, 2021.

52. Wang, J.; Yu, C.W.; Cao, S.J. Technology pathway of efficient and climate-friendly cooling in buildings: Towards carbon neutrality. Indoor Built Environ. 2021, 1-5. [CrossRef]

53. Yang, R.J. Overcoming technical barriers and risks in the application of building integrated photovoltaics (BIPV): Hardware and software strategies. Autom. Constr. 2015, 51, 92-102. [CrossRef]

54. Yadav, S.; Panda, S. Thermal performance of BIPV system by considering periodic nature of insolation and optimum tilt-angle of PV panel. Renew. Energy 2020, 150, 136-146. [CrossRef]

55. Alrashidi, H.; Ghosh, A.; Issa, W.; Sellami, N.; Mallick, T.K.; Sundaram, S. Thermal performance of semitransparent CdTe BIPV window at temperate climate. Sol. Energy 2020, 195, 536-543. [CrossRef]

56. Wenjun, Q.; Shibo, B.; Xuesong, C.; Wei, W. Assembled Energy Self-sufficient CIGS Display Unit: Future-oriented BIPV Exploration. Architect. J. 2019, S2, 96-99.

57. Jianqiang, B.; Ruike, Y. The Studies of Low Carbon Building; China Environmental Press: Beijing, China, $2015 ;$ p. 112. 